\title{
Left atrial myxoma in a child diagnosed by ultra-sound
}

\author{
A. J. S. NiCHOLls* \\ M.B., B.S., D.C.H., D.Obst.R.C.O.G. \\ M. A. Goodman $\dagger$ \\ M.B., B.S., F.R.C.S., F.R.C.S.E. \\ R. B. PRIDIE + \\ M.B., B.S., F.F.R., D.M.R.D. \\ Departments of Paediatrics, North Middlesex Hospital; \\ Thoracic Surgery, The Hospital for Sick Children, Great Ormond Street; and \\ Department of Clinical Cardiology, Royal Postgraduate Medical School, Hammersmith Hospital
}

\section{Summary}

A case of left atrial myxoma in a child is presented. The diagnosis was made using ultra-sound and confirmed at operation.

The results of our investigations are reviewed in the light of other authors' experience with this disease. The use of ultra-sound in recognizing this condition is discussed.

LEFT atrial myxoma is the commonest primary cardiac tumour and the clinical features are well documented (Yater, 1931; Goodwin, 1964).

The technique of mitral echocardiography using ultra-sound waves generated by a piezo-electric transducer directed at the anterior cusp of the mitral valve was first described in 1954 by Edler \& Hertz. Effert \& Domanig (1959) showed that echoes arising from a left atrial myxoma were visible behind those of the anterior cusp of the mitral valve in diastole so that the normally echo-free space is filled by multiple dots. Reports of four atrial myxomas occurring in adults and demonstrated by this method (Schattenberg, 1968; Wolffe, Popp \& Feigenbaum, 1969; Popp \& Harrison, 1969) have appeared previously. This is the first record of a child with an atrial myxoma in whom the diagnosis has been made by ultra-sound.

\section{Case report}

A 7-year-old boy was referred by his general practitioner to the North Middlesex Hospital on the 21 February, 1970, with a 1-week history of pyrexia which had not responded to erythromycin. He had pain in the right lower leg and ankle and later similar

\footnotetext{
* Present address: City Hospital, Hucknall Road, Nottingham.

$\dagger$ Present address: Perth Royal Hospital, Perth, Western Australia.

$\ddagger$ Supported by a grant from The British Heart Foundation.
}

pain on the left side severe enough to prevent himf walking or standing. He had had intermittent ankleळ pain for 1 year. His general health was good and the family history was unremarkable.

On examination his temperature was $37.6^{\circ} \mathrm{C}$ a he had a malar flush. The pulse rate was $120 / \mathrm{mm}$. He was in sinus rhythm and had a blood pressure $110 / 70 \mathrm{mmHg}$. There was no cardiomegaly. Ausculy tation revealed a variable presystolic murmur a $\mathrm{d} d \mathbb{R}$ loud first sound. No other abnormality could detected on full systematic examination.

\section{Investigations}

The $\mathrm{Hb}$ was $11.3 \mathrm{~g} / 100 \mathrm{ml}$; WBC $11,800\left(52^{\circ} \%\right.$ neutrophils, $30 \%$ lymphocytes, $12 \%$ monocytes some atypical, and $6 \%$ eosinophils); reticulocyteso less than $2 \%$. ESR $85 \mathrm{~mm} / \mathrm{hr}$ (Westergren). Protein? electrophoresis showed raised alpha $a_{1}$ and alpha globulins with a normal total protein and albumen? content. The ASO titre was less than 50 units $/ \mathrm{ml}$ and the SCAT was less than 1 in 8. The Paul Bunnel:ANF and Widal tests were negative. Blood and urines cultures were sterile. Urine microscopy showed tent. red cells per high power field but no white cells or casts. Chest X-ray, IVP and ECG were normal.

He was treated as if he had rheumatic fever pending results of investigations and given a course of ampicillin and salicylates. However, he continued to have a sleeping tachycardia of $120-130$ beats $/ \mathrm{min}$, क low grade pyrexia between $37.2^{\circ} \mathrm{C}$ and $38.7^{\circ} \mathrm{C}$ and intermittent proteinuria and haematuria.

On the 13 March he had a transient episode in which he became unconscious for $5 \mathrm{~min}$ and had ô left facial weakness which resolved within a few minutes. On regaining consciousness he vomitedk and complained of a left frontal headache.

An ultra-sonic mitral echogram performed on the 25 March showed that the valve was not thickened 


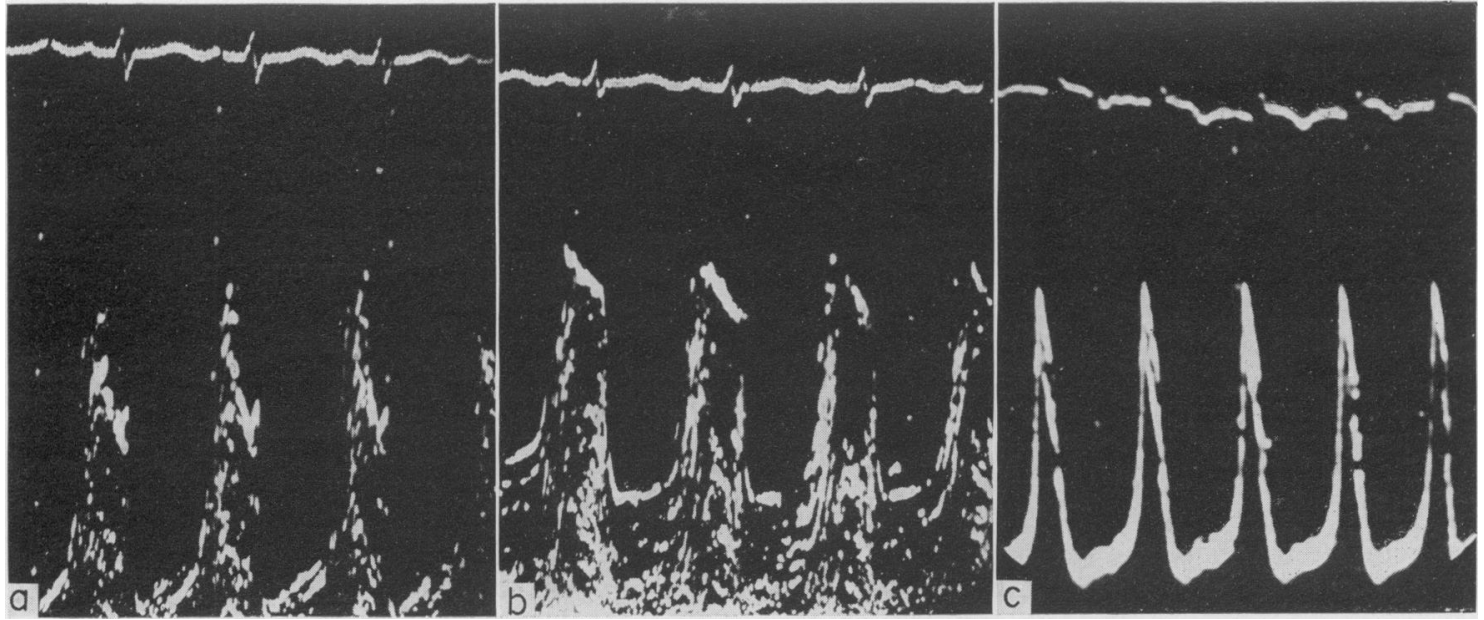

Fig. 1. (a) Pre-operative echogram-no obstruction to the mitral valve. (b) Pre-operative echogram-mitral valve obstructed. (c) Postoperative echogram.
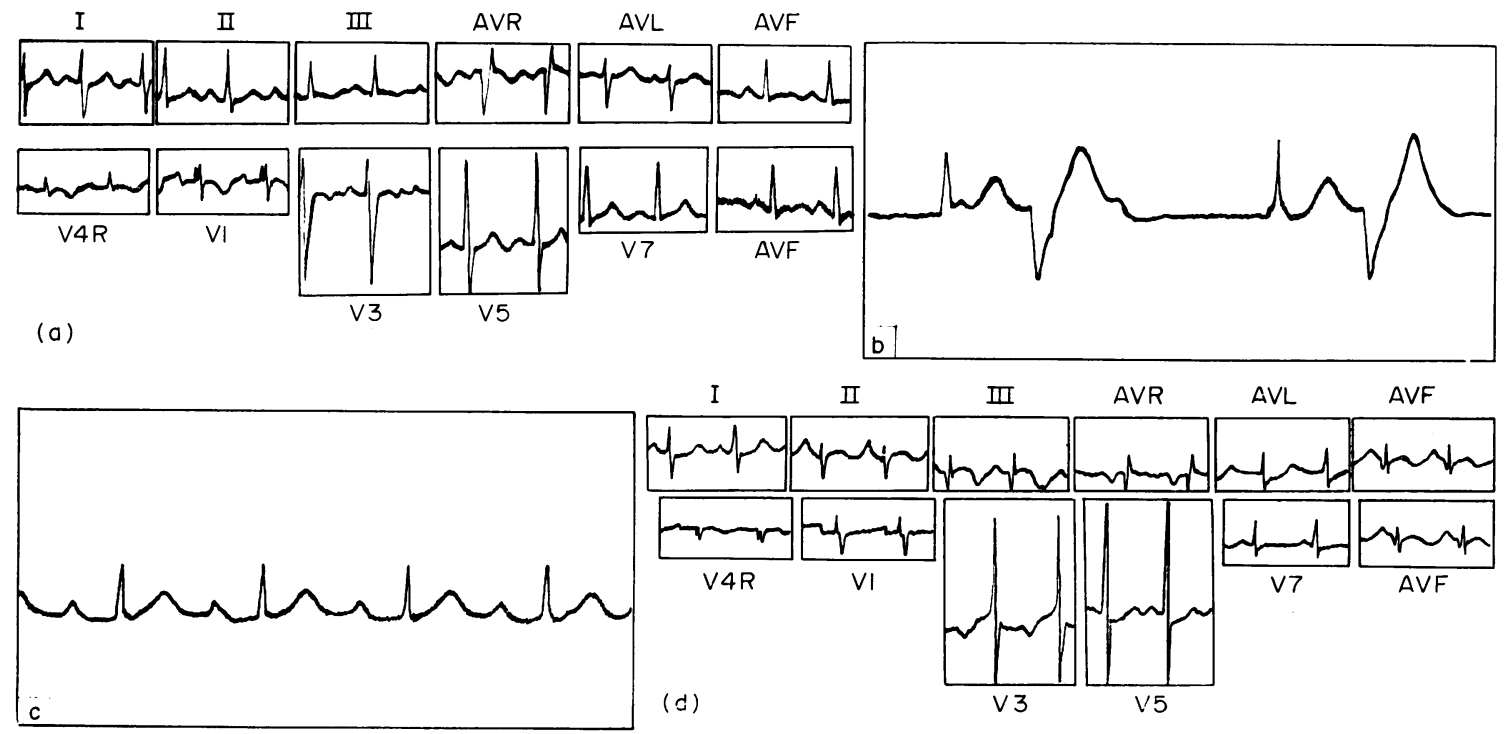

FIG. 2. (a) Normal ECG on admission to hospital. (b) ECG at time of infarct. (c) ECG taken 10 min later. (d) ECG taken $15 \mathrm{hr}$ later showing well developed posterior infarction.

and was normally mobile. During some beats the diastolic closure rate was normal at $85 \mathrm{~mm} / \mathrm{sec}$ (Fig. 1a). At other times the diastolic closure rate was reduced to $30 \mathrm{~mm} / \mathrm{sec}$ indicating that there was intermittent mitral obstruction (Fig. 1b). Throughout all cardiac cycles, multiple echoes were visible behind the anterior cusp of the mitral valve in diastole. This indicated the presence of a reflecting body behind the anterior valve cusp in diastole, where only blood should be. This is diagnostic of a left atrial myxoma.

On the 31 March he complained of chest pain, vomited and collapsed with pallor, bradycardia
(30-40 apex beats/min), absent peripheral pulses and shallow respiration. ECG showed complete heart block with a ventricular rate of 40, ST depression and $T$ wave inversion in lead III. The rate then increased and became nodal with ectopic beats. Sinus rhythm returned later, the ectopic beats disappeared and he recovered consciousness.

Following this episode the leg pulses below the femorals and the left arm pulses could not be felt. Fifteen hours later the SGOT was 97 units and the SLDH 680 units. ECG showed a posterior infarct(Fig. 2). Cardiac catheterization was performed, and 
following an injection of radio-opaque material into the main pulmonary artery, a large filling defect was demonstrated in the right side of the left atrium.

\section{Operation}

He was transferred to The Hospital for Sick Children, Great Ormond Street, and exploration of the left atrium was performed on the 4 April by $\mathrm{Mr} \mathrm{D}$. J. Waterston using cardio-pulmonary by-pass. A large myxoma measuring $5 \mathrm{~cm} \times 4 \mathrm{~cm} \times 4 \mathrm{~cm}$ arising from the posterior wall of the left atrium was found and excised. After the cardiac incision had been closed, the apex of the heart was elevated and a well demarcated infarct was found on the posterior surface. He had an uneventful convalescence and has now returned to school and normal activity.

The pedal pulses have returned but he still does not have any pulses in the left arm though the circulation appears to be adequate. The ECG has shown evolution of the posterior infarct, the $T$ waves returning to their upright position; the ESR and SLDH have returned to normal levels and the postoperative echogram (Fig. 1c) has no echoes behind the anterior mitral cusp. The tachycardia prevents the diastolic closure rate being measured.

\section{Comment}

In spite of the absence of ECG evidence of carditis and lack of associated joint signs, rheumatic fever was initially diagnosed as the most likely cause of tachycardia, limb pains and a high ESR in a child. The ASO titre of less than 50 units was further evidence against rheumatic fever, an opinion recently reinforced by Davis's view (1970) that a low ASO titre should stimulate the search for an alternative diagnosis.

Subacute bacterial endocarditis in the absence of a past history of rheumatic heart disease or cardiovascular defect is uncommon. It was the search for such a focus producing emboli, viz. an abnormal mitral valve, that led to the use of ultra-sound. This apparatus can record echoes from the anterior cusp of the mitral valve and detect abnormalities of anatomy and function. If the atrium contains a tumour protruding through the valve-ring in atrial systole, the characteristic picture seen in Fig. 1a and $1 \mathrm{~b}$ will be produced. This picture is not seen when the tumour is wholly within the atrium.

Fever, tachycardia and raised ESR are nonspecific and the mechanisms of their production in myxoma are obscure. Abnormal serum proteins have also been observed, the abnormality lying usually in an increased gamma globulin, but in this case it was alpha $_{1}$ and alpha $a_{2}$ globulins. Goodwin et al. (1962) and Goodwin (1968) postulated a general poisoning of the body tissues by the myxoma, the mechanism being release of some substance (e.g. mucopoly- saccharides) into the circulation by the tumour Also suggested was hepatic anoxia and subsequen liver cell necrosis due to low cardiac output (Good $\frac{3}{\mathrm{~d}}$ win, 1964). Destruction of erythrocytes by the tumour? or an auto-immune cause similar to the post-cardiotomy syndrome were suggested by Goodwin (1968) $\overrightarrow{\bar{s}}$ to account for the anaemia. A higher reticulocyte count than the $2 \%$ found in this child would havebeen expected.

\section{Discussion}

Syncopal attacks due to myxoma are commonlyes attributed to sudden decrease in cardiac output when the tumour obstructs the mitral orifice. Inadults with an atheromatous coronary tree this $\vec{\omega}$ decrease may be sufficient to cause anoxic myocardiaf damage and infarction without occlusion. Directo coronary occlusion is another alternative. The well demarcated infarct found at operation seems almost $-\vec{v}$ certainly the result of the syncopal attack andir rhythm change 4 days earlier. The tumour was con- + sidered to be discharging emboli then and although $\infty$ rare, coronary emboli have been reported in this ${ }_{\circ}^{+}$ condition. Two cases of myxoma tumour emboli $\mathrm{Fn}^{-}$ coronary vessels were described by Harvey (1959) and one by Heath (1968). We feel that this represerits a further case. However, Nadas \& Curtis-Ellis $\&$ n (1968) described a 13-year-old child who died following sudden onset of heart block. Necropsy showed는 obstruction to the mitral valve by a myxoma but $\mathrm{xo}_{\overrightarrow{0}}$ coronary embolus.

Kroopf \& Peterson (1957) described a patient win left atrial myxoma who developed acute anterioro myocardial infarction. Necropsy failed to show coronary occlusion and the authors' suggested compression of the left coronary artery by displacement by the large tumour in the left atrium.

Large vessel emboli have been reported in both윽 adults and children. Embolectomy was rejected in this case because the circulation to the limb was? good. This does raise the theoretical complication of aneurysm-formation at the site of the embolus; 3 Burton \& Johnson (1970) have described multiple cerebral aneurysms following embolization of 3 . myxoma tissue to the cerebral circulation with proliferation and fragmentation of the intima at the site of impaction.

Although left atrial myxoma is rare, this diagnosis must be considered in any patient who is embolizing음 without apparent cause, and the ultra sound technique is a simple and atraumatic means to investigate? the left atrium.

\section{Acknowledgments}

We are grateful to Dr I. G. Wickes and Mr D. J. Waterston for permission to publish the details of this patient under their care, and to Dr B. G. Wells who performed the cardiac $\mathbb{D}$
catheterization. 


\section{References}

Burton, C. \& Johnson, J. (1970) Multiple cerebral aneurysms and cardiac tumours. New English Journal of Medicine, 282, 35 .

DAvis, E. (1970) Criterion for diagnosis of rheumatic fever. Lancet, i, 1043.

Edler, I. \& Hertz, C.H. (1954) The use of ultra-sound reflectoscope for the continuous recording of heart walls. Kungliga Fysiografifk Sallskapts $i$ Lund. Forhandlingar, 24, 5.

Effert, S. \& Domanig, E. (1959) The diagnosis of intra atrial tumours and thrombi by the ultra-sonic echo method. German Medical Monthly, 4, 1.

GoodwiN, J.F. (1964) Diagnosis of left atrial myxoma. Lancet, i, 464.

Goodwin, J.F., Stanfield, C.A., Steiner, R.E., Bentall, H.H., SAYed, H.M., Gloom, V.R. \& Bishop, M.B. (1962) Clinical features of left atrial myxoma. Thorax, 17, 91.

GoodwIN, J.F. (1968) The spectrum of cardiac tumours. American Journal of Cardiology, 21, 307.
Harvey, J.C. (1957) Myxoma of the left auricle. Annals of Internal Medicine, 47, 1067.

Heath, D. (1968) Pathology of cardiac tumours. American Journal of Cardiology, 21, 315.

Kroopf, S.S. \& Peterson, C.A. (1957) Anaplastic myxoma of left atrium, A.M.A. Archives of internal medicine, 100, 819.

Nadas, A.S. \& Curtis-Ellison, R. (1968) Cardiac tumours in infancy. American Journal of Cardiology, 21, 363.

PoPP, R.L. \& Harrison, D.C. (1969) Ultra-sound for the diagnosis of atrial tumours. Annals of Internal Medicine, 71, 785.

SChattenberG, T.T. (1968) Echocardiographic diagnosis of left atrial myxoma. Mayo Clinic Proceedings, 43, 620.

Wolff, S.P., Popp, R.L. \& Feigenbaum, H. (1969) Diagnosis of atrial tumours by ultra sound. Circulation, 39, 615.

YATER, W.M. (1931) Tumours of the heart and pericardium. Archives of Internal Medicine, 48, 627.

\title{
Duogastrone-induced hypokalaemic nephropathy and myopathy with myoglobinuria
}

\author{
A. B. S. Mitchell \\ M.B., M.R.C.P. \\ West London Hospital, Charing Cross Group of Hospitals, London, W.6
}

CARBEnoxolone sodium and the parent substance, liquorice, have an aldosterone-like effect, and may give rise to oedema, hypertension and hypokalaemia (Baron \& Nabarro, 1968; Hausmann \& Tarnoky, 1968). The hypokalaemia may cause a myopathy, perhaps with myoglobinuria, or a nephropathy or death. Reports of these complications are listed in Table 1.
Hypokalaemia, with all the above effects apart from death, occurred in a patient while taking positioned-release capsules of carbenoxolone (Duogastrone) in the recommended dose, and within the recommended course duration.

\section{Case report}

N.M., a 46-year-old Pakistani male waiter, who

TABLE 1. List of the reported cases in which complications of hypokalaemia have occurred during therapy with liquorice or its derivatives (Number of patients in each report noted in parenthesis)

\begin{tabular}{|c|c|c|c|c|}
\hline & \multicolumn{2}{|c|}{ Muscle weakness } & \multirow{2}{*}{ Nephropathy } & \multirow{2}{*}{ Death } \\
\hline & Myopathy & With myoglobinuria & & \\
\hline Liquorice preparations & $\begin{array}{l}\text { Cayley (1), 1950; Heard, Camp- } \\
\text { bell \& Hurley (6), 1950; Strong } \\
\text { (2), 1951; Mollaret, Goulon \& } \\
\text { Tournilhac (1), 1960; Garcin } \\
\text { et al. (1), 1961; Giroire et al. (1), } \\
\text { 1961; Jenny et al. (1), 1961; } \\
\text { Salassa, Mattox \& Rosevear (1), } \\
\text { 1962; Chodkiewicz, Clay \& } \\
\text { Hecaen (2), 1963; Minvielle, } \\
\text { Cristol \& Badach (2), 1963; } \\
\text { Holmes et al. (1), 1970 }\end{array}$ & $\begin{array}{l}\text { Geerling (1), 1966; Gross, } \\
\text { Dexter \& Roth (1), } 1966\end{array}$ & $\begin{array}{l}\text { Chodkiewicz } \\
\text { et al. (1), } 1963\end{array}$ & $\begin{array}{l}\text { Heard et al. (4), } \\
1950^{*} \text {; Roussak } \\
(1), 1952\end{array}$ \\
\hline $\begin{array}{l}\text { Carbenoxolone sodium: } \\
\text { as Biogastrone } \\
\text { as Duogastrone }\end{array}$ & $\begin{array}{l}\text { Morgan, Donald \& McAndrew } \\
\text { (1), } 1966 \dagger \\
\text { Muir, Laithwaite \& Wood (1), } \\
1969\end{array}$ & $\begin{array}{l}\text { Mohamed, Chapman \& } \\
\text { Crooks (1), } 1966 \\
\text { Forshaw (1), } 1969 \ddagger\end{array}$ & & \\
\hline
\end{tabular}

